\title{
Skinner and Vygotsky's Understanding of Resilience in the School Environment
}

\author{
Rosana Angst Pasqualotto, Suzane Schmidlin Löhr, Tania Stoltz \\ Department of Education, Federal University of Paraná, Curitiba, Brazil \\ Email: roangst@gmail.com
}

Received 9 August 2015; accepted 9 October 2015; published 13 October 2015

Copyright $@ 2015$ by authors and Scientific Research Publishing Inc.

This work is licensed under the Creative Commons Attribution International License (CC BY). http://creativecommons.org/licenses/by/4.0/

(c) (i) Open Access

\begin{abstract}
Resilience is defined as the ability to endure situations of risk, overcome them and use them as sources of life strengthening and learning. This paper aims to analyze resilience in the school environment according to two classic perspectives in education: radical behaviorism (Skinner) and the socio-historical approach (Vygotsky). According to the socio-historical perspective, resilience can be understood as a higher psychological function resulting from an individual's self-regulatory processes. According to the behavioural approach, whenever a person is exposed to aversive situations and finds strategies to remove them, avoidance skills are developed in order to find sources of reinforcement even during adversity. Both approaches consider that resilience is socially and culturally built, nevertheless, the need exists to consider the epistemological and conceptual differences between the two authors.
\end{abstract}

\section{Keywords}

Resilience, School, Skinner, Vygotsky

\section{Introduction}

This paper seeks to analyze resilience from the points of view of Vygotsky and Skinner. Although neither of these authors examines the theme of resilience in depth, nevertheless this paper proposes to contribute to this theme based on concepts they put forward. It is important to emphasize that this study does not intend to equate the ideas of these two authors, given that their epistemological and philosophical backgrounds are distinct, but rather the intention is to analyze elements of each of their theories capable of contributing to understanding the concept of resilience. Analysis based on different viewpoints enriches the debates and interventions made by professionals, providing them with the opportunity to experience different approaches to this psychological phenomenon. Lucci (2009) emphasizes that there are few studies that concentrate on establishing parallels be- 
tween the works of Vygotsky and Skinner.

In addition to primary and secondary sources of Skinner and Vygotsky, this paper is also based on articles retrieved from the Scielo and CAPES databases, using the following keywords: resiliência, resilience, Skinner and Vygotsky. 479 articles were found on Scielo's periodicals website (www.scielo.org). Since the first of these articles was published there has been a significant increase in bibliographical production, especially with effect from 2010. 84,069 published articles were found on the CAPES periodicals website (www.periodicos.capes.gov.br), whereby the first article was published in 1827, and 50,739 articles were published in the last 5 years. The large number of recent articles shows the growing interest in the theme among the academic community. Nevertheless, few articles discuss resilience based on analytical/behavioural concepts and concepts used by the socio-historical approach. An article dating from 2007 was found which analyzes resilience from the socio-historical perspective (Edwards \& Apostolov, 2007), and an article dating from 2010 was found on the Scielo database dealing with resilience according to the cognitive/behavioural viewpoint (Norte et al., 2011).

\section{What Is Resilience?}

People are constantly going through adverse situations, but some people never overcome them, whilst others, even though they suffer, bounce back, learn from the situation and move forward. The term resilience has been used in the scientific literature to characterize such people (Yunes; Szymanski, 2001; Assis, Pesce, \& Avanci, 2006; Rutter, 2007; Busnello, Schaefer, \& Kristensen, 2009; Pike, Danwley, \& Tomaney, 2010). Resilience can be defined as the ability of a person, group or community to go through risk situations, overcome them, but not forget them and rather use them as sources of life strengthening and learning (Assis, Pesce, \& Avanci, 2006). The term has its origins in Physics and was used for the first time by Thomas Young in 1807 (Yunes \& Szymanski, 2001). Young described as being resilient materials which even after having been subjected to a given impact returned to their initial state without suffering harm. The term later became used by Medicine and in the 1950s also began to be applied to the area of Psychology. The pioneer scholars of resilience in Psychology are: Emmy Werner, Ruth Smith, Michael Rutter (Yunes \& Szymanski, 2001) and Frederich Flach (Flach, 1991). According to Fortes, Portuguez and Argimon (2009, p. 456), there are three branches of studies on resilience:

[...] the North American branch, essentially pragmatic and centred on the individual; the European branch, with greater psychoanalytical focus and an ethical perspective; and the Latin American branch, with a community focus, directed towards social issues as a logical response to the problems experienced in that society, such as violence, marginalization, vulnerability etc.

Literature on resilience tends to focus on two main classes of factors: risk factors and protection factors. According to Poletto and Koller (2008), risk factors are potentially negative situations occurring during human development and trigger disadaptation to the environment. However, these situations can be mitigated or reduced by protection factors. These are characterized as influences capable of changing the direction of disadaptation, facilitating the overcoming of aversive events.

Rutter (2007) emphasizes the importance of understanding resilience by attempting to learn how protective characteristics develop and how they are able to modify an individual's personal trajectory. This author highlights that the ability to be resilient is not innate or related to personality, but rather learned in the environment in which the person is situated. Promoting resilience does not mean protecting others from all the adversities they will face during their lives, but rather making resources available that may be able to contribute to the productive handling of delicate situations with a high potential for harming development. One of the alternatives in this sense is defended by Pinheiro (2004) and Werner (2006), who argue that for resilience to exist there need to be confrontations in life. Authors such as Rutter (2007) and Werner (2006) point out that no one can avoid going through adversities, but if they know there are people around them whom they can count on, the impact of the difficult situation may be lessened, i.e., they have a group they can count on for reference and support. Assis, Pesce and Avanci (2006) state that there are three kinds of protection factors: individual factors, relating to the ability to solve problems in an autonomous manner in accordance with one's individual resources; family factors, encompassing the support of people in whose help one can trust at times of adversity; and social environment factors, which reinforce the feeling of security and stability in relation to friends, teachers or other significant people.

Considering that both the theory of Skinner and that proposed by Vygotsky emphasize the social and cultural environment in the constitution of a subject, both theories are put forth here to provide the basis for reflections 
aimed at understanding the phenomenon of resilience.

\section{Resilience from the Behavioural Perspective}

During his entire academic trajectory, Skinner (1904-1990) dedicated himself to understanding human behaviour, seeking to identify patterns and forms of modification, and this knowledge provided the basis for the behavioural approach. One of the key articles produced by him, entitled Selection by Consequences (1981), discusses how we are the fruit of selective pressures: the selection of species, as studied by Darwin, the selection of certain classes of behaviour, linked to the unique history of each person which is also the object of psychological analysis, and selection arising from cultural pressures which result in certain practices being accepted and maintained in specific cultures for generations. Mankind's relationship with the external environment is, according to Skinner, a dialectic one. In his words: "men act upon the world, and change it, and are changed in turn by the consequences of their action" (Skinner, 1957/1978: p. 1). According to behavioural precepts, a person emits a behaviour because of something in the interaction with the environment that makes them behave that way. The environment is therefore seen as a key unit for the emission of a given class of behaviour (De Rose, 1997; Matos, 1997). When the environment to which the person is exposed involves other individuals, this involves what is called social behaviour, defined as the behaviour that two or more people emit in relation to a common environment. It must be taken into consideration with regard to the emission of behaviours that whether or not a given class of behaviours is seen to be adequate relates to value judgements and, for the most part, is defined by the respective culture. We are therefore impelled to emit behaviours that are accepted and approved by the cultural context in which we are situated (Skinner, 1953/2003).

If someone is exposed to aversive situations and finds strategies that enable them to be eliminated, thus avoiding having to be subjected to them, they will develop avoidance skills and their action will be reinforced negatively (Whaley \& Malott, 1980; Sidman, 1995). A person who adopts different ways of dealing with the issue until the best way is found increases their repertoire of behaviours, thus favouring behavioural variability. A person who has greater behavioural variability has more tools available to deal with a constantly changing world. That is to say, a person who seeks strategies to avoid an aversive condition can broaden their repertoire of behaviours in ways which make them better prepared for new situations they may be exposed to in the world. The concept of avoidance is different to the concept of escape, as according to Whaley \& Malott (1980), escape occurs when someone comes into contact with an aversive situation for the first time and seeks strategies so that the situation does not cause them harm; whereas avoidance is when someone has already experienced the aversive situation and seeks strategies to avoid going through it again. Nevertheless, both avoidance and escape require a creative response, finding alternatives to deal with the current aversive situation (escape) or a situation which may occur in the near future (avoidance). Even so, it must be highlighted that avoidance is not always the best response, nor is it always considered to be a resilient behaviour.

Today there are authors who defend that a person is not born resilient, but rather that this ability is built according to exchanges and experiences occurring during adversities, that is to say, one is not always resilient, one behaves in a resilient way at a given time (Peres, Mercadante, \& Nasello, 2005; Pike, Dawley, \& Tomaney, 2010).

The behaviour pattern of continuing to resist even when faced with difficulties, typical of resilient people, may indicate that the person in question has been submitted to schedules of intermittent reinforcement with high response rates. In the case of intermittent schedules, not all responses are reinforced and, in order to reach high response rates, there is a gradual increase in the number of responses required so that reinforcement is released. On the other hand, a continuous reinforcement schedule (CRF), whereby all target behaviour, when emitted, is reinforced, has probably formed part of the learning history of people with a low degree of resilience, given that continuous reinforcement is extremely fragile. If someone has been reinforced positively in a continuous manner and then their behaviour ceases to be reinforced, they may emit that pattern of responses, thus characterizing low tolerance of frustration (Whaley \& Malott, 1980).

Behaviours maintained through intermittent reinforcement schedules (when some responses are positively sequenced and others of the same nature are not reinforced) may acquire high resistance to frustration and to the extinction of that behaviour. This happens because people learn in practice that that when they emit a given behaviour it may not always have pleasant consequences, but that if they maintain that class of responses there is a possibility of achieving what they want, in the future. They learn this as part of their history of learning, leading 
to them remember that there were times when this class of behaviour was reinforced, and that if they are able to overcome them, they may obtain (although they do not know when) this reinforcement again (Millenson, 1975; Catania, 1999; Skinner, 1953/2003).

Adversities are inherent to everyone's life, but what differentiates someone who has a repertoire of resilience is their ability to seek reinforcements within their reach in order to solve problems, this being the time to define which resources will be used (or not) to withstand current adversities (Angst, 2013). When a person is faced with diversities and seeks new forms of behaviour, different to those they used before, behavioural variability can be said to be taking place. According to Hunziker and Moreno (2000) behavioural variability is characterized by behaviours emitted as a result of the environment and not initially expected, whereby their appearance and maintenance are reinforced by the consequences. Behavioural variability results in new behaviours being emitted, increasing the probability of reinforcement and thus establishing conditions for the repertoire to be increased and to become more complex. As a result of this process a person becomes more flexible and open to changes, since they have learned that changes can be positive.

Identifying what controls behaviour opens possibilities for engaging a person in classes of behaviours that are productive for solving such behaviours, or for selecting the contexts in which the emission of these behaviours is more efficient for solving them. Seeking different alternatives for solving problems increases the chances of the emission of a response which does indeed resolve the issue, increasing the person's repertoire of behaviours, i.e., it provides greater behavioural variability. The experience of not having all their requests, needs and desires met, mobilizes people to seek alternative solutions, strengthening them in the face of life's difficult situations, enhancing their repertoire of resilient behaviours.

Returning to selection by consequences as described by Skinner (1981), it is easy to note that people with greater behavioural variability are more apt to adapt to new situations, continuing to respond even when the reinforcement of repertoires that were effective in the past is no longer made available. In a continually changing world, people who have this way of dealing with situations are better equipped to survive. It can therefore be said that people with a greater number of resilient behaviours are more likely to be selected both on the ontogenetic level and also, in the long term, on the phylogenetic level.

\section{Resilience from the Perspective of Vygotsky}

Vygotsky (1896-1934) is considered to be an historical-cultural and interactionist theoretician. For him people, as a synthesis of multiple determinations, are active in their social and cultural relations, and it is only through these relations that people develop (Van der Veer \& Valsiner, 1994; 1999). Vygotsky emphasizes that humans, because they develop based on an historical and cultural context, have aspects that differentiate them from apes, given that apart from having inferior aspects in the same way as primates, they are capable, by using instruments and signs, of achieving a higher level in the development of symbolization, memory, attention, awareness, abstract reasoning, intentional behaviour and so forth (Vygotsky \& Luria, 1994; Vygotsky, 2000). Vygotsky states that we develop through the mediation that occurs between the environment and the individual, whereby all the higher functions appear twice during the development of the child: firstly in social activities, in the form of interpsychological functions, and later as reasoning and intrapsychological functions (Vygotsky, 1991).

For Vygotsky it is language that enables communication between a child and other people, and when language is converted into the internal environmental, it becomes a mental function and generates reasoning. Communication not mediated by language is known to be characteristic of more primitive animals and does not enable higher levels of development to be reached (Vygotsky, 1991; Vygotsky, Luria \& Leontiev, 1996). In other words, in human beings social and psychological processes are determined by tools of a social nature which transform objects into cultural signs or significant instruments. By learning to use instruments of their own culture and, above all, the linguistic system, humankind develops new forms of activity that are truly human (Stoltz, 2010).

A person's degree of cultural development is expressed not only by the knowledge they have already acquired, but also by the possibility of dealing with cultural objects in the outside world, with mediators, using their psychological processes in an adequate manner. For Vygotsky and Luria (1994), learning takes place when the student interacts with other more experienced people, and at school this person is above all the teacher.

Vygotsky (1998) states that the actual zone of development is the level of already completed mental functions which enable this level to be manifested in the independent solving of problems. Notwithstanding, he explains 
that it is more important to determine a person's potential level of development than their actual level of development. Their potential level of development is shown through the ability to make use of new instruments and cultural objects based on external forms of regulation that give rise to this learning. The concept of the zone of proximal development thus establishes the space in which the teacher exercises mediation. The zone of proximal development, or ZPD, is the distance existing between the actual level of development (what a person is capable of doing on their own) and the level of potential development (what a person is capable of learning when aided by others). Each person has different zones of proximal development, arising through different learning experiences within a social and cultural context, which are always undergoing transformation. The human mind is therefore social in its origin. This is understood to be so because in the view of Vygotsky, learning precedes development rather than coinciding with it. Learning opens different channels of development.

As a person's activities evolve, that which initially appears on the level of potential development turns into actual development. This in turn opens the way for a new level of potential development. The process of internalization is responsible for external regulation (interpsychological processes) becoming internal regulation (self-regulated intrapsychological processes). It is interesting to recall that intrapsychological processes involve experiencing socially shared significations that manifest themselves in a given context. They therefore involve the marked presence of emotion and provide a space for the development of a person's subjectivity which is evident in the dialectics between interpsychological and intrapsychological processes. Self-regulation implies humankind doing mediated activities within their context and this in turn enables the expression of other forms of social interaction by individuals within their context, providing an opportunity for new learning and development both by the participants in that context and by the individuals themselves (Luria, Leontiev, \& Vygotsky, 1991).

Social interaction can be characterized as an action which constitutes humankind, in which one individual relates with another by means of the mediation of language, signs, signals and instruments. If this interaction takes place with quality, it will be capable of generating new development, moving on from a process that was lower to one which is higher (Cabrera \& Villalobos, 2007). According to Ratner (1995), this implies that people not only develop by interacting with others, but that they also built themselves, given that they form their reactions based on the stimuli coming from the environment in the form of behaviour standards, concepts, aspirations and motives that have been organized socially. "Interaction and communication with others drive people to explain their intentions and significations so that they can be recognized by others” (Ratner, 1995: p. 29).

For Díaz, Neal and Amaya-Willians (1996), self-regulation is defined as the flexibility used to guide a behaviour in accordance with contingent rules that have been internalized. Self-regulation is a behaviour that has an objective or a plan that is self-formulated, whereby instruments and mediators are used to solve problems. The interactions involving this type of activity initially occur in childhood, mainly with the child's first carers, and continue throughout a person's entire life. It is important to note that self-regulation is different to the concept of self-control. Self-control is defined by the authors mentioned above as the ability developed to obey commands of adults without them being present. That is to say, it is a behaviour organized in rigid connections between stimulus and response, whereby the suggestions of the environment stimulate the response. The distinction between the two concepts is that in the case of self-regulation, a child not only internalizes the commands of adults, as occurs with self-control, but also takes on the role of regulator which was formerly the role of the adult.

Based on Vygotsky, resilience can be understood as a higher psychological function resulting from an individual's self-regulating processes. In turn, these processes arise from external regulation occurring within the historical and cultural context. Through processes of internalization, which imply external regulation being turned into self-regulation, an individual creates their own ways of dealing with risk situations and being strengthened by them. This transition involves a negotiation with the person's culture and creativity based on the selection and control of what is available in their social and cultural context. Resilience here is understood not as being static, but rather as a dynamic movement of interaction with the social and cultural world (Edwards \& Apostolov, 2007). Resilience would therefore require self-regulation, given that it relates to the means used by an individual to go through an adverse situation, seek forms of overcoming this moment with the aid of different mediators, and thus be internally prepared when similar situations occur again (Edwards \& Apostolov, 2007). By interacting with successive regulating social contacts over time, people achieve higher levels of self-regulation and are able to solve new problems in an independent manner. They develop resilient behaviours when they go through an adverse situation and are capable of self-regulating themselves, although this ability can only be developed based on a social and cultural context (Edwards \& Apostolov, 2007). In order for this behaviour to arise, 
the quality of social interactions is fundamental, leading to transformations of processes on progressively higher levels. The quality of social interactions depends on the extent to which they enable an individual to absorb cultural tools and objects and significant exchanges that lead to the development of self-regulating processes, in the case of resilience, in the face of adverse and unfavourable situations.

\section{Resilience and Education: Student and Teacher Facing Adversities}

Many challenges currently exist in the school system, including the lack of motivation on the part of teachers and students, this being prejudicial for the teacher-student relationship and for the learning of formal and informal contents (Arroyo, 2009). This issue can be analyzed from the point of view of resilience, risk factors and protection factors existing in the school environment.

One hypothesis for explaining this situation may be that many students, when starting school, may have had a life history in which they received from the environment everything they wanted and thus developed a low level of frustration. When they learn from an early age that they can get everything they want in the relationship with their carers, they do not understand why they are not able to get their wishes met in other environments, such as school. This type of conduct is capable of generating problems in their relationship both with teachers and colleagues.

Based on Skinner's concepts, it is easy to understand how a person kept in a schedule of continuous reinforcement is weak in maintaining the response. Thus, when faced with the first difficulties in the new environment, a student may stop emitting responses that do not have positive consequences and engage in other behaviours, at times prejudicial to the teacher-student relationship, in an attempt to obtain attention or other kinds of reinforcement. This pattern of behaviour often arises from the culture in which we live, which encourages parents, from an individualist viewpoint, to never wish to frustrate their children, thus resulting in them not developing resilient characteristics which will be necessary in life outside the protective family context. When a teacher identifies this situation, they can contribute so that the school, instead of maintaining the dysfunctional pattern developed by the family, is sensitive enough to scale up the level of requirement, helping the child to have resilient behaviours, thus gradually raising the response rate needed to release reinforcement. In this way, little by little, a child moves from continuous reinforcement to schedules of intermittent reinforcement which produce more response.

From Vygotsky's perspective, a child that is used to having all its wishes fulfilled may have difficulty in interacting with its peers and, in this sense, may be less benefitted by external regulation, thus compromising the development of its self-regulation. According to the socio-historical viewpoint, the purpose of a school is to be a place of constant learning that leads to a child's development. The role of the educator would therefore be precisely not to do everything the child wants, but rather help it to learn new things which in turn would provide the opportunity for new development, expressed through self-regulation.

Another problem frequently arising in the present day relates to formal learning. Students who are not able to do their assignments satisfactorily and frequently have unsatisfactory performance at school may become frustrated and in the future this may lead to their dropping out of school. As such, schools can also be considered to be a risk factor (Assis, Pesce, \& Avanci, 2006; Busnello, Schaefer, \& Kristensen, 2009). Skinner (1989/1995) does not accept the use of punishment in education. Punishment occurs when an aversive contingency is included following the emission of a given behaviour. This process is exemplified in the educational context in situations in which students, after dedicating themselves to doing an assignment, are given low marks or have their performance criticized. The aversive consequences following the behaviour class of studying and doing school activities, represented by not achieving the objectives expected, may lead to students extinguishing their behaviour of going to school, thus resulting in what is referred to as dropping out of school. If teaching were graduated and modulated, respecting individual needs, challenges would be put in place, but these would be in keeping with each student's conditions. The support given by the teacher, guiding a student at times of difficulty, would serve as a protective safety net instead of generating drop-out. Lack of planning in teaching, across the board programmes aimed at all students without taking specific needs into consideration, may be considered, from this perspective, as risk factors for the development process.

From Vygotsky's point of view, at school consideration should be given above all to the relationship between scientific and spontaneous knowledge, between abstract and concrete, theory and practice, respecting the very movement of the method of historical/dialectic materialism: starting with concrete action, undergoing analysis 
and then reaching the transforming action that expresses concrete reasoning. As such, the dialectic exchange between students and teachers, the promotion of conceptual conflicts and working with praxis are fundamental to promoting the development of self-regulation. Another essential aspect lies in the need for greater support in introducing new contents or skills and the gradual withdrawal of this support as new real and potential development establishes itself.

School is an important social apparatus which can contribute to the development of resilience (Poletto \& Koller, 2008). The school environment is considered to be one of the most efficacious spaces for promoting resilience owing to its having two important characteristics: firstly, it brings together diverse human systems; secondly, it provides the possibility of linking teachers to students, within a perspective of human development, encompassing protection factors rather than risk factors (Fajardo, Minayo, \& Moreira, 2010). It must be remembered that schools can be both a protection factor, whereby they are an environment in which teachers and students feel at ease to dialogue and seek solve conflicts, and a risk factor, whereby they are hostiles place in which teachers and students are expected only to perform tasks and where they do not feel welcome and at ease (Howard \& Johnson, 2004).

Skinner (1989/1995), when describing the school of the future, sees it as an agreeable place where it is pleasurable for students to be. In this context, learning would be stimulating, because students would be participating in programmes with organized contents, meeting their individual needs, so that they would be able to experience success in their activities. When mastering contents, students would experience intrinsic reinforcement, in this case the sensation of happiness and well being for having mastered the topic, and would then be able to move on to the next stage of learning. Under this proposal, all students would have the means to reach more elaborate levels of knowledge and mastery of contents, achieving more complex levels of learning at different times along their academic trajectory. Teachers, in addition to promoting resources that facilitate learning, would be accessible to students, giving individualized support to those needing it, given that teaching technologies would enable each student to work at different stages of the education process. Skinner therefore proposes the use of elements that promote healthy development, seeking to minimize the risk factors linked to the context in question. By demanding that students have an increasingly elaborate repertoire, teachers contribute to their gradually learning to cope with frustrations, thus facilitating the development of resilience.

From Vygotsky's perspective, human development occurs as a result of learning acquired in specific social and cultural contexts, and schools are seen as the place par excellence for absorbing socially produced and historically accumulated knowledge. They are one of the places where self-regulation can be encouraged when adequate social mediators are available. Teachers deal continually in the classroom with their students' zones of proximal development, and by progressively challenging them to learn significant contents, through the negotiation of significations and the production of feelings, they act as promoters of resilience.

Vygotsky highlights the role of schools and teaching in the development of higher psychological functions that arise through mediated activity. In this sense, the role of schools can be understood to be that of making possible access to cultural tools and, through these tools, enabling the absorption of historically built knowledge, as well as the development of imagination and creativity, in terms of self-regulation of emotion, will and the construction of new knowledge. Based on Vygotsky, these processes are understood to always arise from external and interpsychological regulation between people, and can be seen as involving the negotiation of significations and the production of new senses by the subject, through intrapsychological processos (Luria, Leontiev, \& Vygotsky, 1991; Stoltz, 2010).

Both the behavioural perspective and Vygotsky's perspective emphasize the importance of the social and cultural environment for human development. Given that schools are the environment in which children spend most of their day, and that teachers are the professionals who are in constant contact with the children there, it is of relevance that teachers know how to deal with problems and ways of solving them in schools (Howard \& Johnson, 2004; Hodder et al., 2011). One of the characteristics of a good teacher is stimulating students to find different forms of learning in accordance with their needs and encouraging them to continually want to improve. In this aspect, convergence exists between what Skinner and Vygotsky defend.

Although thus far the focus has been on the resilience of students, it can also be seen that resilient teachers can contribute to students developing more, since when resilient teachers are faced with difficulties, they do not give up so easily and are able to better organize the learning programme so as to take into account each student's needs, as per Skinner's perspective, or become a better mediator of learning, as proposed by Vygotsky.

When teachers have resilient characteristics, they appear to their students as a positive model in relation to 
facing up to difficulties, so that their students may also develop resilience in the school environment by imitating their teacher. It is through interaction in the school environment that students can learn to deal with different types of difficulties occurring as they develop and which in turn can help them in facing future difficulties proper to life.

\section{Conclusion}

Resilience as seen from both the behavioural approach and from Vygotsky's approach can be understood as a dynamic and socially constructed process and involves constant interaction with the environment. Since the social environment favours interaction between people and people's interaction with objects, it is essential for the emission of behaviours and the constitution of the subject under both approaches. Ratner (1995), in keeping with the socio-historical viewpoint, emphasizes that children's cognitive and emotional development can be attributed to the complex social interactions to which they are exposed, since there would be no progress with the development of a body operating in an isolated manner. The value placed on the importance of the community for an individual's development stands out as the core of Vygotsky's approach, since learning occurs first on the interpsychological level and is then internalized and develops on the intrapsychological level. Keller and Schoenfeld (1968, p. 380), in accordance with the behavioural approach, state that "It is hard, if not impossible, to think of a person's straightforward operant activity that does not show to some degree, the penetrating influence of the teachings of the community”. When a person faces difficulties or a given specific situation that they are not able to solve by making use of the tools they have always used situations, they will need to create new strategies. This indicates behavioural variability, this being an essential aspect for adaptation to new contexts. Resilience is, according to the behavioural approach, the fruit of behavioural variability. Someone who is resilient probably tried several ways of solving problem situations until their efforts enabled them to achieve a given objective.

Despite having taken different research approaches and having different philosophical and epistemological backgrounds, Vygotsky and Skinner show the undoubted belief that social interaction generates learning and can lead to development. For Vygotsky, learning comes first and opens channels for development. For Skinner, learning is equivalent to development.

For Vygotsky (1998, pp. 117-118)

(...) an essential aspect of learning is the fact of it creating a zone of proximal development; that is to say, learning awakens several internal proposes of development, which are only capable of operating when a child interacts with people in its environment and when cooperating with its colleagues. Once they have been internalized, these processes become part of a child's acquisition of independent development.

The conclusion is therefore reached that for Vygotsky learning is related to the development of higher psychological functions.

Both Skinner and Vygotsky put forward their theories explaining how human development occurs. Skinner emphasizes the consequences of action, specifically reinforcement and schedules of reinforcement for acquiring a more elaborate repertoire. Vygotsky brings the concepts of higher psychological functions, zone of proximal development, mediation, process of internalization and self-regulation. Both authors place value on the possibility of learning and developing constantly and do not an individual as being the only one responsible for their learning.

For both the behavioural and the socio-historical approach, resilience is socially and culturally built and involves constant interaction with the environment. Taking Skinner and Vygotsky's concepts as a basis, it is possible to broaden the understanding of resilience, this being something that is being increasingly studied in the scientific community. The criticism that Vygotsky (2012) makes with regard to the behavioural approach relates to its atomism. For Vygotsky, this approach begins with the parts in order to reach the whole and understands the whole as the sum of the parts. Vygotsky (2012) also criticizes the behavioural approach principally because of its not taking into consideration the background of the formation of higher psychological functions through cultural development.

It is important to highlight that the concept of resilience arose through the study of adversities, this being a factor to which everyone is frequently exposed in a continually changing society. Resilience therefore presumes exposure to situations found in life and, as part of this process, the building of skills that enable adversities to be overcome. 
Schools can act as important places for students to develop resilient characteristics. The relationships established in this context can both drive resilience, as illustrated in situations in which students need to adapt to normative transitions related to the different cycles of study, and can also take on characteristics that inhibit resilience, made evident in cases in which students are unable to cope with difficulties present in the school environment.

Creating educational processes that promote resilience in the school context is a challenge. It involves promoting a non-chaotic and organized learning environment, which values clear and consistent rules and is a place in which it is safe to learn. By building mechanisms aimed at protecting students from violence and risk factors, proposing situations with increasing levels of difficulty, capable of promoting an individual's adaptation in the face of adversity, schools will be playing an important role in structuring people with resilient characteristics and who will probably have better chances of adapting in a society in which new adversities are appearing all the time.

Skinner and Vygotsky provide two alternatives for analyzing the education process in relation to resilience. Dialogue between the two viewpoints is relevant because of the way in which each of them analyzes social issues and their importance for human development. It must be emphasized that neither of the approaches considers that an individual becomes a copy of the social milieu, but rather that the social environment is seen as the genesis of the processes of learning and development at a given moment in time.

Veiga (2013) emphasizes that in the future the Psychology of Education will need to take into consideration environmental aspects of the education and family system as a model of prevention and health promotion, becoming more creative, productive and intervening. The Psychology of Education, when studying the teaching/learning process, needs, at some point in time, to reflect about resilience. Returning to Skinner and Vygotsky, it is important to bear in mind that both of them in their written works indicate that they recognize both personal and social aspects encompassing the school environment, and analyze how they affect a student's academic performance. The production of knowledge about resilience can be benefitted by studies that seek to deepen conceptual understanding of the theme and link this with practical applications. These are aspects which this article has sought to approach.

\section{References}

Angst, R. (2013). Habilidades sociais e resiliência em acadêmicos de licenciaturas. [Social Skills and Resilience in Degree Course Students]. Dissertação (Mestrado em Educação)—Setor de Educação, Curitiba: Universidade Federal do Paraná. 108f.

Arroyo, M. G. (2009). Ofício de mestre: Imagens e autoimagens. [The Art of Being a Master: Images and Self Images]. Petrópolis: Vozes.

Assis, S. G., Pesce, R. P., \& Avanci, J. Q. (2006). Resiliência: Enfatizando a proteção dos adolescentes. [Resilience: Emphasizing the Protection of Adolescents]. Porto Alegre: Artmed.

Busnello, F. de B., Schaefer, L. S., \& Kristensen, C. H. (2009). Eventos estressores e estratégicas de coping em adolescentes: Implicações na aprendizagem. [Stressful Events and Coping Strategies among Adolescents: Implications for Learning]. Revista Semestral da Associação Brasileira de Psicologia escolar e Educacional (ABRAPEE), 13, 315-323.

Cabrera, C. M. de, \& Villalobos, J. (2007). El aspecto socio-cultural del pensamiento y del lenguaje: Visión Vygotskyana. [The Sociocultural Aspect of Thought and Language: Vygotsky's View]. Educere, 11, 411-418.

Catania, C. (1999). Aprendizagem: Comportamento, linguagem e cognição. [Learning: Behaviour, Language and Cognition] (4th ed.). Porto Alegre: Artes Médicas.

De Rose, J. C. C. (1997). O que é comportamento? [What Is Behaviour?] In R. A. Banaco, (Org.), Sobre comportamento e cognição: Aspectos teóricos, metodológicos e de formação em análise do comportamento e terapia cognitivista (Vol. 1, pp.79-81). São Paulo: Arbytes.

Díaz, R. M., Neal, C. J., \& Amaya-Willians, M. (1996). As origens sociais da auto-regulação. [The Social Origins of SelfRegulation]. In L. C. Moll (Ed.), Vygotsky e a Educação (pp. 123-149). Porto Alegre: Artes médicas.

Edwards, A., \& Apostolov, A. (2007) A Cultural-Historical Interpretation of Resilience: The Implications for Practice. Outlines: Critical Practice Studies, 9, 70.

Fajardo, I. N., Minayo, M. C. de S., \& Moreira, C. O. F. (2010). Educação escolar e resiliência: PolÍtica de educação e a prática docente em meios adversos. [School Education and Resilience: Education Policy and teaching Practice in Adverse Situations]. Ensaio: Avaliação e Políticas Públicas em Educação, 18, 761-773.

http://dx.doi.org/10.1590/S0104-40362010000400006 
Flach, F. F. (1991). Resiliência: A arte de ser flexível. [Resilience: The Art of Being Flexible] (1st ed.). São Paulo: Saraiva.

Fortes, T. F. R., Portuguez, M. W., \& Argimon, I. I. D. L. (2009). A resiliência em idosos e sua relação com variáveis sociodemográficas e funções cognitivas. [Resilience in the Elderly and Its Relationship with Sociodemographic Variables and Cognitive Functions]. Estudos de Psicologia, 26, 455-463. http://dx.doi.org/10.1590/S0103-166X2009000400006

Hodder, R. K., Daly, J., Freund, M., Bowman, J., Hazell, T., \& Wiggers, J. (2011). A School-Based Resilience Intervention to Decrease Tobacco, Alcohol and Marijuana Use in High School Students. BMC Public Health, 11, 722. http://dx.doi.org/10.1186/1471-2458-11-722

Howard, S., \& Johnson, B. (2004). Resilient Teachers: Resisting Stress and Burnout. Social Psychology of Education, 7 , 399-420. http://dx.doi.org/10.1007/s11218-004-0975-0

Hunziker, M. H. L., \& Moreno, R. (2000). Análise da noção de variabilidade comportamental. [Analysis of the Notion of Behavioural Variability]. Psicologia: Teoria e Pesquisa, 16, 135-143.

Keller, F. S., \& Schoenfeld, W. N. (1968). Princípios de psicologia. [Principles of Psychology]. São Paulo: Herder.

Lucci, M. A. (2009). Um estudo sobre as propostas de Skinner e as de Vygotsky: A contribuição de uma aproximação. [A Study of the Proposals of Skinner and Vygotsky: The Contribution of an Approximation]. Interação, 2, 1339-1347.

Luria, A. R., Leontiev, A., \& Vygotsky, L. S. (1991). Psicologia e pedagogia: Bases psicológicas da aprendizagem e do desenvolvimento. [Psychology and Pedagogy: Psychological Bases of Learning and Development]. São Paulo: Moraes.

Matos, M. A. (1997). O behaviorismo metodológico e suas relações com o mentalismo e o behaviorismo radical. [Methodological Behaviourism and Its Relationships with Mentalism and Radical Behaviourism]. In R. A. Banaco (Org.), Sobre comportamento e cognição: Aspectos teóricos, metodológicos e de formação em análise do comportamento e terapia cognitivista (Vol. 1, pp. 57-69). São Paulo: Arbytes.

Millenson, J. R. (1975). Princípios de análise do comportamento. [Principles of Behaviour Analysis]. Brasília: Coordenada.

Norte, C. E., Souza, G. G. L., Pedrozo, A. L., Mendonça-De-Souza, A. A. C. F., Figueira, I., Volchan, E., \& Ventura, P. R. (2011). Impacto da terapia cognitivo-comportamental nos fatores neurobiológicos relacionados à resiliência. [The Impact of Cognitive Behaviour Therapy on Neurobiological Factors Related to Resilience]. Revista de Psiquiatria Clínica, 38, 43-45.

Peres, J. F. P., Mercante, J. P. P., \& Nasello, A. G. (2005). Promovendo resiliência em vítimas de trauma psicológico. [Promoting Resilience in Victims of Psychological Trauma]. Revista de Psiquiatria do Rio Grande do Sul, 27, 131-138. http://dx.doi.org/10.1590/s0101-81082005000200003

Pike, A., Dawley, S., \& Tomaney, J. (2010). Resilience, Adaptation and Adaptability. Cambridge Journal of Regions, 3, 5970. http://dx.doi.org/10.1093/cjres/rsq001

Pinheiro, D. P. N. (2004). A resiliência em discussão. [Resilience in Discussion]. Psicologia em Estudo, 9, 67-75. http://dx.doi.org/10.1590/S1413-73722004000100009

Poletto, M., \& Koller, S. H. (2008). Contextos ecológicos: Promotores de resiliência, fatores de risco e de proteção. [Ecological Contexts: Resilience Promotors, Risk Factors and Protection Factors]. Estudos de Psicologia, 25, 405-416. http://dx.doi.org/10.1590/S0103-166X2008000300009

Ratner, C. (1995). A psicologia sócio-histórica de Vygotsky: Aplicações contemporâneas. [Vygotsky’s Sociohistorical Psychology: Contemporary Applications] (L. L. de Oliveira, Trad.). Porto Alegre: Artes Médicas.

Rutter, M. (2007). Resilience, Competence and Coping. Child Abuse \& Neglect, 31, 205-209. http://dx.doi.org/10.1016/j.chiabu.2007.02.001

Sidman, M. (1995). Coerção e suas implicações. [Coercion and Its Implications]. Campinas: Editorial Psy.

Skinner, B. F. (1953/2003). Ciência e comportamento humano. [Science and Human Behaviour] (11th ed., J. C. Todorov, \& R. Azzi, Trad.). São Paulo: Martins Fontes.

Skinner, B. F. (1957/1978). O comportamento verbal. [Verbal Behaviour]. São Paulo: Cultrix.

Skinner, B. F. (1981). Selection by Consequences. Science, 213, 501-504. http://dx.doi.org/10.1126/science.7244649

Skinner, B. F. (1989/1995). Questões recentes na análise comportamental. [Recent Issues in the Analysis of Behaviour] (2nd ed., A. L. Neri, Trad.). Campinas: Papirus.

Stoltz, T. (2010). Por que Vygotsky na educação? [Vygotsky in Education, Why?] In E. C. Ramos, \& K. Franklin (Orgs.), Fundamentos da educação: Os diversos olhares do educar (pp. 171-181). Curitiba: Juruá.

Van Der Veer, R., \& Valsiner, J. (1994). The Vygotsky Reader. Oxford: Blackwell.

Van Der Veer, R., \& Valsiner, J. (1999). Vygotsky: Uma síntese. [Vygotsky: A Synthesis] (3rd ed.). São Paulo: Loyola.

Veiga, F. H. (2013). Psicologia e educação. [Psychology and Education]. In F. H. Veiga, \& J. Magalhães (Eds.), Psicologia da educação: Teoria, investigação e aplicação envolvimento dos alunos na escola (pp. 27-40). Lisboa: Climepsi. 
Vygotsky, L. S. (1991). Aprendizagem e desenvolvimento intelectual na idade escolar. [Learning and Mental Development in School-Age Children]. In A. Leontiev, L. S. Vygotsky, \& A. R. Luria (Orgs.), Linguagem, desenvolvimento e aprendizagem (pp. 1-17). São Paulo: Editora Moraes.

Vygotsky, L. S. (1998). A formação social da mente: O desenvolvimento dos processos psicológicos superiores. [Mind in Society: The Development of Higher Psychological Processes] (6th ed., J. C. Neto, L. S. M. Barreto, \& S. C. Afeche, Trad.). São Paulo: Martins Fontes.

Vygotsky, L. S. (2000). A construção do pensamento e da linguagem. [Thought and Language]. São Paulo: Martins Fontes.

Vygotsky, L. S. (2012). El problema del desarrollo de las funciones psíquicas superiores. [The Problem of the Development of Higher Mental Functions]. In L. S. Vygotsky (Ed.), Obras escogidas (Vol. II, pp. 11-46). Madrid: Machado Grupo de Distribución, S.L.

Vygotsky, L. S., \& Luria, A. (1994). Tool and Symbol in Child Development. In R. Van Der Veer, \& J. Valsiner (Eds.), The Vygotsky Reader. Oxford: Blackwell Publishers.

Vygotsky, L. S., Luria, A., \& Leontiev, A. (1996). Estudos sobre a história do comportamento: O macaco, o primitivo e a criança. [Studies on the History of Behaviour: Ape, Primitive and Child] (L. L. de Oliveira, Trad.). Porto Alegre: Artmed.

Werner, E. E. (2006). What Can We Learn about Resilience from Large-Scale Longitudinal Studies? In S. Goldstein, \& R. B. Brooks (Eds.), Handbook of Resilience in Children (pp. 91-105). New York: LLC.

Whaley, D. L., \& Malott, R. W. (1980). Princípios elementares do comportamento. [Elementary Principles of Behaviour] (M. A. Matos, M. L. Ferrara, \& C. F. Santoro, Trad). São Paulo: EPU.

Yunes, M. A. M., \& Szymanski, H. (2001). Resiliência: Noção, conceitos afins e considerações críticas. [Resilience: Notion, Like Concepts and Critical Considerations]. In J. Tavares (Org.), Resiliência e educação (pp. 13-42). São Paulo: Cortez. 